Jurnal Konstruksi Hukum | ISSN: 2746-5055

Vol. 2, No. 2, Mei 2021, Hal. 338-343| Tersedia online di

https://www.ejournal.warmadewa.ac.id/index.php/jukonhum

DOI: https://doi.org/10.22225/jkh.2.2.3233.338-343

\title{
TINDAK PIDANA PELANGGARAN LALU LINTAS DAN UPAYA PENANGGULANGANNYA PADA MASA PANDEMI COVID-19
}

\author{
I Gede Krisna, I Nyoman Gede Sugiarta, I Nyoman Subamiya \\ Fakultas Hukum, Universitas Warmadewa, Denpasar - Bali, Indonesia \\ gedekarisna@gmail.com, nyomansugiartha@gmail.com, doktorsubamia@gmail.com
}

\begin{abstract}
Abstrak
Lalu lintas sebagai suatu proses yang terjadi di jalan raya, yang mana keberadaannya memiliki peran yang amat penting dan sentral dalam kehidupan di masyarakat, sehingga tak dapat dipungkiri keberadaannya sebagai salah suatu kebutuhan yang dimiliki masyarakat berupa suatu sarana guna memenuhi kegiatan mobilisasi untuk memenuhi setiap kebutuhan dasar manusia. Pelanggaran lalu lintas kerap terjadi dan menyebabkan mobilisasi menjadi terganggu maka diperlukannya tindak pidana bagi masyarakat yang tidak mematuhi aturan lalu lintas. Dalam penulisan ini metode yang digunakan adalah metode penelitian empiris yaitu mengkaji peraturan perundang-undangan yang berlaku dengan mengaitkan dengan permasalahan yang dibahas. Teknik pengumpulan data primer dilakukan dengan melakukan wawancara dengan anggota Kepolisian di bidang pelanggaran lalu lintas di Kepolisian Daerah Gianyar. Tujuan penelitian ini untuk mengetahui faktor-faktor yang mempengaruhi terjadinya pelanggaran lalu lintas khususnya di daerah Bali serta upaya yang dapat dilakukan dalam menanggulangi pelanggaran lalu lintas di wilayah hukum Kepolisian Daerah Bali. Hasil penelitian menunjukkan bahwa faktor-faktor penyebab terjadinya pelanggaran lalu lintas yaitu faktor substansial, struktur, hingga culture dari masyarakat. Adapun upaya penanggulangannya adalah dengan pemberlakuan patroli, penempatan pos jaga, pengaturan, hingga sosialisasi kepada masyarakat.
\end{abstract}

Kata kunci : Pelanggaran, Lalu lintas dan Penanggulangan.

\begin{abstract}
Traffic as a process that occurs on the highway, where its existence has a very important and central role in society, so it cannot be denied that its existence is one of the needs of the community in the form of a means to fulfill mobilization activities to meet every basic need. Traffic violations often occur and cause mobilization to be disrupted, hence the need for criminal acts for people who do not obey traffic rules. The method used in this research is an empirical, which is to research about the applicable laws and regulations by relating the issues discussed. The primary data collection technique was carried out by conducting interviews with members of the Police in the field of traffic violations at the Gianyar Regional Police. The purpose of this research is to determine the factors that influence the occurrence of traffic violations, especially in the Bali area as well as the efforts that can be made to overcome traffic violations in the jurisdiction of the Bali Regional Police. The results shows that the factors causing traffic violations were substantial factors, structure, and culture from the community. Efforts to overcome this include enforcing patrols, placing guard posts, arranging them, and socializing them to the public.
\end{abstract}

Keywords: Violations, Traffic and Countermeasures.

\section{PENDAHULUAN}

Lalu lintas sebagai suatu proses yang terjadi di jalan raya, yang mana keberadaannya memiliki peran yang amat penting dan sentral dalam kehidupan di masyarakat, sehingga tak dapat dipungkiri keberadaannya. Sebagai suatu kebutuhan yang dimiliki masyarakat dengan mana merupakan suatu sarana guna memenuhi kegiatan mobilisasi untuk memenuhi setiap kebutuhan dasar lain mereka. Dengan melakukan lalu lintas, adanya hasrat dalam memanfaatkan jalan raya dengan baik untuk kepentingan mobilisasi atau berpindah tempat dari satu tempat ke tempat lainnya. Oleh karena hal tersebut, upaya menegakkan hukum dan keadilan terkait kegiatan yang terjadi di sepanjang jalan raya diperlukan.

Beberapa poin yang menjadi perhatian seperti halnya faktor penentu dari peri laku pengguna jalan entah dengan berkendara motor atau pun mobil dan kendaraan lainnya serta bagaimana pengaruhnya dalam kepadatan arus lalu lintas yang terjadi, begiru pula perilaku pengguna jalan yang 
taat serta disiplin atau tidaknya alam berkendara, itulah yang menyebabkan pelanggaran banyak terjadi di jalan dalam berlalu lintas. Perbuatan ini begitu membahayakan penggunajalan baik dirinya atau orang lain bahkan hingga melayangkan nyawa seseorang. Hal ini jika dikaitkan dengan upaya penegakkan hukum yang ada dimana untuk saat ini masih belum optimal penerapannya dan penegakannya di lapangan. Hal yang tak lain disebabkan karena (1) belum memadainya kondisi serta jumlah kendaraan saat ini yang beroperasi di masyarakat, (2) Kurang baiknya sikap mental dari pengendara, (3) Penanganan pelanggaran lalu lintas yang masih kurang optimal dalam penegakannya karena kurangnya sikap bijaksana dalam penerapan hukumnya.

Berdasarkan makin meningkat dan berkebangnya laju kemajuan teknologi dalam industri otornotif menimbulkan akibat semakin meningkat pula masyarakat sebagai konsumen unruk menggunakan kendaraan di jalan raya. Dengan begini, secara tak sadar, berbagai dampat dapat muncul dari kegiatan ini dimana meningkatnya pula perbuatan-perbuatan yang dapat mengganggu aktivitas di jalan raya seperti ketertiban, ketentraman hingga kelancaran berlalu lintas. Terdapatnya banyak gangguan yang terjadi ini juga turut berdampak pada aturan yang ada, dirnana penggunaan jalan raya dengan tertib serta teratur sulit untuk direalisasikan, sebut saja jika terjadi kecelakaan dalam berkendara, ini dapat menimbulkan berbagai dampak seperti kemacetan, korban jiwa, dan hal lainnya yang tidak menguntungkan.

Perilaku dalam mengendara yang menyimpang merupakan salah satu faktor penyebab terjadinya kecelakaan dalam berkendara di jalan, hal ini di sebabkan karena tidak ditaatinya aturan berkendara sebagai mana diarur dalam aturan hukum yang berlaku. Selanjutnya, begitu padatnya arus lalu lintas membuat berbagai macam kemungkinan tak menentu dari keadaan lalu lintas yang sedang berjalan. Ini membuat suasana di jalan semakin panas ditambah cuaca yang tak mendukung pula, sehingga pelanggaran tak terelakkan terjadi, sebut saja saling salip, penggunaan trotoar oleh pengendara untuk mempercepat pengaksesanjalan dan lain sebagainya. Untuk itu, penerbitan UndangUndang No. 3 tahun 1965, serta disempurnakan dengan UU No. 14 tahun 1992 menjadi salah satu solusinya, yang di dalamnya terdapat aturan terkait pelanggaran Jalu Jintas yang dapat terjadi dalam berkendara.

Pelanggaran lalu lintas di Kepolisian Daerah Gianyar tahun 2017 mencapai 14.857, tahun 2018 mencapai 15.157, tahun 201916.064 meningkat dibandingkan dengan tahun sebelumnya, ini semua membuktikan masih kurang sikap atau rasa peduli yang di mil iki masyarakat selaku pengguna jalan, dalam hat berperilaku yang semestinya di jalan raya, sehingga hat ini mengakibatkan penyimpangan seperti pelanggaran lalu lintas, ini juga ada kaitannya dengan berbagai faktor penyebabnya seperti apakah factor structural, substansialnya ataukah mungkin culturenya, dengan kata lain, aparat penegaknya, hukumnya ataukah masyarakatnya. Disamping itu ada pula faktor ekstemal berkaitan dengan merebaknya virus corona atau COVID-19 yang terjadi belakangan ini juga memberikan dampak tertentu terkait kondisi lalu lintas saat ini, seperti penurunan pengguna jalan yang berlalu lalang terkait adanya pembatasan kegiatan yang dilakukan pemerintah, yang mana berbeda dari tahun-tahun sebelumnya.

Lebih lanjut, pelanggaran lalu lintas merupakan tindakan yang dilakukan oleh seseorang yang sedang mengemudikan kendaraan umum atau kendaraan bermotor serta pejalan kaki yang bertentangan dengan peraturan perundang-undangan yang berlaku (Nurfauziah, 2021). Hal ini dapat terjadi dikarenakan beberapa faktor contoh pengemudi dan pemakai jalan kurang peduli dengan aturan yang telah diatur oleh pemerintah, konstruksi jalan yang kurang baik rambu lalu lintas yang kurang jelas (Anindhito \& Maerani, 2018) Dalam hal ini menurut (Fauzi, 2020) harus direalisasikannya peraturan perundang-undangan yang mengatur masalah lalu lintas dan angkutan jalan raya sebab memiliki tujuan yang sangat penting yaitu menciptakan ketentraman bagi masyarakat dalam berlalu lintas.

Berdasarkan penjelasan diatas, penelitian ini bertujuan untuk mengetahui faktor-faktor yang mempengaruhi terjadinya pelanggaran lalu lintas khususnya di daerah Bali serta upaya yang dapat dilakukan dalam menanggulangi pelanggaran lalu lintas di wilayah hukum Kepolisian Daerah Bali.

\section{METODE PENELITIAN}

Penelitian ini digunakan metode empiris, yang mana rujukannya berdasarkan pada pendekatan kasus, serta melalui wawancara terhadap petugas. Ada beberapa data primer adalah data yang diperoleh di tempat penelitian yaitu di wilayah hukum Kepolisian Negara Republik lndonesia Daerah Bali, teknik 
pengumpulan data dilakukan dengan melakukan wawancara dengan anggota Kepolisian di bidang pelanggaran lalu lintas di Kepolisian Daerah Gianyar serta berdasarkan data jumlah pelanggaran lalu lintas yang ada. Selain itu penggunaan Undang-Undang Lalu Lintas dan Angkutan jalan No.22 tahun 2009 serta KUHP hingga buku-buku literatur, jurnal-jurnal terkait juga membantu penelitian ini.

\section{HASIL DAN PEMBAHASAN}

\section{Faktor-Faktor Terjadinya Pelanggaran Lalu Lintas pada Masa Pandemi Covid-19}

Dalam memutuskan suatu perkara yang dilakukan oleh Haki, dengan mana dalam ha! ini terkait perkara pelanggaran lalu lintas, surat tilang disini memiliki peran yang penting, yaitu sebagai barang bukti selama proses pemidanaan dari pemeriksaan hingga persidangan. Sejalan pendapat Mr. H.M. Tirtamidjaja, yang menerangkan bahwa dalam melakukan pembuktian suatu perkara pidana, barang bukti merupakan aspek terpenting yang harus diperoleh baik oleh jaksa maupun polisi untuk melanjutkan proses pidana selanjutnya, dari situlah poin terpenting selama penyidikan. Dari sinilah peran hakim harus jeli melihat hubungan antara alat bukti yang ada satu sama lainnya, dimulai dari barang bukti, keterangan saksi, ahli, hingga pengakuan dari tersangka sendiri. Maka hakim harus dapat menarik simpulan dari pemaparan tersebut.

Pelanggaran lalu lintas sering kita dengar dengan istilah tilang di Indonesia merupakan pelanggaran yang ranah lingkupnya termasuk hukum pidana, mengingat perbuatan tersebut merupakan perbuatan yang dilarang oleh peraturan yang berlaku sehingga akibarnya dilakukan pemidanaan dengan penerapan sanksi pidana. Efektivitas penegakan hukum dapat kita lihat dari penerapan sanksinya atau system sanksinya sendiri. Sebut saja contohnya pelanggaran penggunaan helm saat berkendara dan kepemilikan Surat izin Mengemudi (Soekamto,1983:6).

Terjadinya pelanggaran terhadap suatu perundang-undangan, tentu ada faktor-faktor penyebabnya yaitu sebagai berikut

1. Yang pertama ada dari faktor substansinya atau hukum itu sendiri, ini diartikan sebagai pada peraturan yang ada dan diterapkan di masyarakat.

2. Selanjutnya pada faktor struktumya yaitu aparat penegak hukum sebagai orang yang berwenang dalam melakukan pengawasan serta penertiban terhadap pelanggaran yang terjadi. Sebagaimana dalam bukunya Tugas dan Peranan Jaksa dalam Pembangunan, Djoko Prakoso mengemukakan mengenai aparat penegak hukum yang merupakan penggerak hukum tersebut. Hukum ltu statis dan hanya diam, ibarat janji, melalui penggunaannya oleh para penegak hukumlah hukum itu dapat berguna dan bermanfaat dengan moral di dalamnya, begitu pula seperti janji yang terwujud melalui peran penegak hukum itu sendiri (Prakoso, 1984).

3. Masih kurang memadai dan layaknya sarana serta fasilitas dalam penegakkan hukum begitu pula kondisi jalan raya yang masih banyak terjadi kerusakan serta kurang perhatian dari pihak yang berwenang.

4. Ada pula faktor dari rnasyarakatnya, dimana rasa atau sikap kepedulian yang kurang serta kesadaran akan bahaya dalam penyimpangan berkendara yang sangat minim. Dalam buku Penegakan Hukum karya Soerjono Soekanto, ia mengemukakan bahwa secara ringkas suatu hukum dapat berfungsi dengan baik, jika masyarakatnya memiliki tingkat keparuhan erta kesadaran yang tinggi untuk memahami hukum itu sendiri. Setidaknya dengan itu, fungsi hukum dapat dirasakan (Soekanto, 1983:32). Mayoritas masyarakat tidak mengetahui adanya suatu peraturan, akan tetapi mengetahui isinya, oleh karena isinya sesuai dengan sistem nilai-nilai yang berlaku ini disebabkan karena adanya proses internalisasi (Lubis, 2018).

5. Faktor kebudayaan, yakni sebagai hasil karya, cipta dan rasa yang didasarkan pada karsa manusia di dalam pergaulan hidup (Soekanto, 1983:5).

\section{Upaya Penanggulangan Pelanggaran Lain Lintas Pada Masa Pandemi Covid-19}

Adanya perbedaan dalam penerapan terkait sanksi bagi pelanggar lalu lintas di pengadilan dengan di jalan raya, hal ini dikarenakan adanya penyimpangan dalam penegakan hukumnya oleh oknum tertentu di lapangan. Dalam persidangan, keyakinan hakim merupakan dasar untuk menerapkan sanksi sesuai aruran perundang-undangan yang berlaku, yang disesuaikan dengan beratnya pelanggaran yang dilakukan. Hal ini sesuai dengan ketentuan dalam pasal 54 Undang-undang No. 14 tahun 1992.

Pengaturan dalam Undang-Undang tersebut terkait pada besar ancaman dari pidana serta denda yang dapat dibebankan kepada pelanggar, yang mana dibandingkan Undang-Undang lalu 
Lintas sebelumnya, aturan ini berisi ancaman hukuman jauh lebih berat. Jika dilakukan pengaitan dengan Kalau dikaitkan system yang ada pada KVHP, sebagaimana pasal 10 KUHP mengenai jenis pidana yang diatur, itu hanyalah suatu stelsel hukuman pidana.

Sebagai suaru syarat yang wajib, prinsipnya, setiap pengendara kendaraan diwajibkan memiliki surat izin rnengemudi atau SIM yang mana merupakan surat keputusan tata usaha Negara bahwa orang tersebut layak, mampu dan dianggap mumpuni untuk dapat berkendara di jalan raya. Hal ini sesuai dengan arahan dalam aturan ketentuan pasal 18 Undang-Undang Lalu Lintas dan Angkutan Jalan Nomor 14 Tahun 1992. Beberapa dokumen lain yang wajib dimiliki pengendara yaitu STNK, Surat lulus uji kelayakan kendaraan, dan bukti lainnya yang berhubungan dan dianggap perlu dalam menjamin pengendara dalam berkendara dengan aman, yang mana diatur juga dalam ketenruan dalam aturan hukum yang berlaku (Karyadi, 1999:105).

Perkara terkait pelanggaran lalu lintas disebut sebagai perkara yang sederhana karena proses praperadilannya hanya dapat dihadiri oleh hakirn serta panitera saja, jadi dalam hal ini Jaksa tidak perlu hadir, karena tidak ada kewajiban seperti proses peradilan biasanya. Ini semua dapat dil ihat dalam rujukan pasal 54-57 Undang-Undang No.14 tahun 1992, yang mana perkara pelanggaran lalu lintas masuk dalam bagian dari perkara roll. Begitu pula terkait berita acara pemeriksaan dalam perkara di jalan, hal ini tidak diperlukan, berbeda dengan perkara pidana lainnya. Hal ini dikarenakan perkara ini merupakan kategori perkara yang cepat serta sederhana dalam pemidanaannya jika dilihat dari mulai proses pemeriksaan hingga pelaksanaan persidangan.

Dalam praktek di Pengadilan Negeri Denpasar pada umumnya jumlah denda yang dijatuhkan pada setiap pelanggar ditentukan oleh kebijaksanaan Hakim yang didasarkan atas rasa kemanusiaan, dalam prakteknya saat ini, penjatuhan sanksi pidana denda biasanya berkisar minimum pada Rp 20.000, ini semua bergantung pada berat atau ringannya pelanggaran dilakukan. Tapi kembali lagi atas kebijakan hakirn, biasa saja jumlah tersebut berlaku bagi semua jenis pelanggaran, atau bahkan biasa saja pelanggarannya sama namun denda yang dijatuhkan berbeda kembali lagi kepada rasa kemanusiaan dari kebijakan hakim itu sendiri.

Walau dalam hakikatnya semua orang sama dimata hukum, namun dalam perkara ini, kadang ada perbedaan untuk para pelanggar, sebut saja dari segi jenis kendaraan yang dipakai hingga status pengendara apakah pelajar, sudah bekerja dan lain sebagainya, ini sernata-mata terkait rasa kemanusiaan tadi. Hingga saat ini penjatuhan denda hingga jutaan rupiah masih rare atau jarang terjadi, mengingat bunyi dalam pasal dengan kata atau di dalam nya, lebih banyak yang menerima untuk melakukan kurungan daripada harus membayar denda yang besar, tapi sebaliknya, bagi yang berduit, dengan kesalahan yang berat dapat bebas dengan rnembayar sejumlah denda, yang mana sering menjadi polemic di masyarakat terkait rasa keadilan yang kurang ini.

Denda yang dibayar pelaku atau pelanggar menggunakan system titipan, dimana besamya uang titipan dipatok oleh Ketua Pengadilan negeri yang menangani kasus serta Kapolsek setempat, ini memperhirungkan pula keadaan ekonomi serta rasa keadilan. Namun hat tak membuat turunnya angka pelanggaran yang terjadi, mengingat masih banyak faktor lain yang menyebabkan masih tingginya pelanggaran lalu lintas yang terjadi. Sebut saja faktor aparat penegak hukum atau struktumya, hukum itu sendiri atau substansinya, hingga kesadaran masyarakat yang masih dianggap kurang dalam memahami bahaya dari perilaku menyimpang di jalan raya. ( Wawancara dengan I Ketut Adiyun, Panitera Pengadilan Negeri Denpasar, Hari Senin tanggal 5 Januari 2015.)

Menurut Undang-Undang No. 14 Tahun 1992 tentang lalu lintas dan angkutan jalan, pada dasamya terdiri dari $16 \mathrm{Bab}$ dan 74 pasal. Apabila dilihat dari isi pokok ketentuan undang-undang itu maka ketentuan pidana termasuk di dalam nya, dimana mengenai ketentuan pidana diatur dalam Bab XIII, yang dirnulai pasal 54 sampai pasal 67. Dari hal tersebut dapat dilihat bahwa pengenaan sanksi pidana berupa denda dapat dilakukan untuk kategori pelanggaran yang mana diperbuat oleh pengendara maupun bukan (penumpang, pemilik), selaku yang mengendarai kendaraan tersebut.

Perbedaan permasalahan hukum pidana dengan hukum lain yang ada, ini berada pada pengenaan sanksinya berupa sanksi pidana sesuai dengan pelanggaran yang dilakukan yang mana merujuk pada normanaya itu sendiri. Sedangkan upaya penanggulangan pelanggaran lalu lintas jalan raya menurut lbu AKP Laksmi Tisnadewi Wieryawan selaku Kasat Lantas yaitu

1. Melakukan patroli secara berkala dan rutin atau kontinu

2. Setiap personil dilakukan pengarahan untuk menempati posisi sesuai simpul jalan yang ada

3. Melakukan pengaturan jalannya lalu lintas, sehingga tetap lancar dan terarur 
4. Adanya kegiatan sosialisasi terkait berlalu lintas kepada masyarakat dengan menyasar seperti sekolah, balai desa, dan organisasi lainnya.

5. Melakukan penjagaan yang sama dengan jamnya.

6. Pemberian saran terkait keadaan serta kondisi jalan, dan fasilitasnya jika dirasa adanya kerusakan, atau kurang memadai dan layak untuk dipakai (hasil wawancara dengan ibu AKP Laksmi Tisnadewi Wieryawan, lalu lintas polres Gianyar, hari senin, tanggal11 januari 2021).

\section{SIMPULAN DAN SARAN}

\section{Simpulan}

Berikut ini penulis merangkum beberapa faktor yang mempengaruhi terjadinya pelanggaran lalin khususnya di daerah Bali berasal dari faktor substansinya atau hukum itu sendiri, ini diartikan sebagai pada peraturan yang ada dan diterapkan di masyarakat, faktor strukturnya yaitu aparat penegak hukum sebagai orang yang berwenang dalam melakukan pengawasan serta penertiban terhadap pelanggaran yang terjadi, masih kurang memadai dan layaknya sarana serta fasilitas dalam penegakkan hukum begitu pula kondisi jalan raya yang masih banyak terjadi kerusakan serta kurang perhatian dari pihak yang berwenang, faktor dari masyarakatnya, dimana rasa atau sikap kepedulian yang kurang serta kesadaran akan bahaya dalam penyimpangan berkendara yang sangat minim dan faktor kebudayaan, yakni sebagai hasil karya, cipta dan rasa yang didasarkan pada karsa manusia di dalam pergaulan hidup. Sedangkan upaya yang dapat dilakukan dalam menanggulangi pelanggaran lalu lintas di wilayah hukum Kepolisian Daerah Bali yaitu seperti yang tel ah diterapkan oleh pihak Kepolisian Daerah Gianyar hingga Satpol PP setempat, yaitu dengan memberikan edukasi secara kontinu guna meningkatkan kesadaran masyarakat.

\section{Saran}

a. Diharapkan masyarakat meningkatkan kesadaran hukum akan pentingnya mematuhi peraturan hukum dalam berkendara atau menggunakan jalan raya. Hal ini juga harus didukung dengan ditingkatkannya sarana serta prasarana penunjang dalam berkendara, selain itu pemahaman akan aturan hukum terkait seperti adanya peran media massa untuk memudahkan masyarakat untuk mengetahui dan belajar akan aturan yang ada. Selanjutnya mengenai penting dan perlu diadakan operasi atau razia untuk menertibkan pengendara atau pengguna jalan yang tak patuh perlu dilakukan secara berkala dan rutin

b. Penjatuhan sanksi atau pemidanaan oleh Hakim selaku salah saru penegak hukum diharapkan lebih optimal dan tegas dengan tetap merujuk pada aturan yang berlaku saat ini sehingga penerapan sanksi dapat memberi efek jera bagi para pelaku. Dan tak mungkin dapat memberikan rasa keadilan di dalamnya. Selain itu, meningkatkan wibawa melalui cara menegakkan yang tegas, guna memberikan rasa kepercayaan kepada masyarakat untuk bersikap saling menghormati dalam penindakan pelanggar, sehingga pelanggar tidak mengulangi perbuatannya untuk kedepannya

\section{DAFTAR PUSTAKA}

Anindhito, D., \& Maerani, I. A. (2018). Kebijakan Hukum Terhadap Pelanggaran Lalu Lintas oleh Anak Di Wilayah Polda Jawa Timur. Jurnal Hukum Khaira Ummah, 13(1), 183-192.

Fauzi, R. (2020). Penegakan Hukum Terhadap Pelanggaran Lalu Lintas oleh Anak Sebagai Pengendara Sepeda Motor di Wilayah Hukum Polres Bukittinggi. Pagaruyuang Law Journal, $3(2), 148-163$.

Karyadi, M. (1999). Perundang-Undangan Lalu Lintas dan Angkutan Jalan Raya di Denpasar. Penerbit Poli tea. Bogor.

Lubis, M. R. (2018). Pertanggungjawaban Pelaku Tindak Pidana Lalu Lintas yang Menyebabkan Korban Meninggal Dunia Akibat Kelalaian. Jurnal Hukum KAIDAH: Media Komunikasi Dan Informasi Hukum Dan Masyarakat, 17(2), 97-111.

Marmosudjono, Sukarton. (1983). Penegakan Hukum di Negara Pancasila. Bina Cipta. Jakarta.

Nurfauziah, R. (2021). Perilaku Pelanggaran Lalu Lintas oleh Remaja ditinjau dari Perspektif Konstruksi Sosial. Jurnal Kolaborasi Resolusi Konflik, 3(1), 75-85.

Prakoso, Djoko (1984). Tugas dan Peranan Jakra Dalam Pembangunan. Ghalia Indonesia. Jakarta.

Soekanto, Soerjono. (1983). Faktor-Faktor yang Mempengaruhi Penegakan Hukum. CV. Rajawali. Jakarta. 
Kitab Undang-Undang Hukum Pidana. (n.d.).

Undang-Undang Republik Indonesia Nomor 22 Tahun 2009 tentang Lalu Lintas dan Angkutan Jalan. (n.d.). 